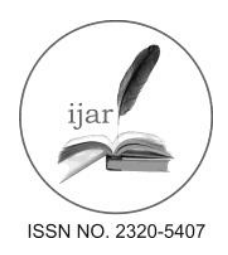

Journal homepage: http://www.journalijar.com

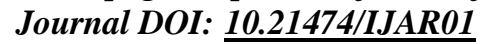

RESEARCH ARTICLE
INTERNATIONAL JOURNAL

OF ADVANCED RESEARCH

מחיח

\title{
CYCLIC UREA ANALOGUES AS INHIBITORS OF JACK BEAN UREASE.
}

Jitender M. Khurana ${ }^{1}$, Vandana Sharma ${ }^{1}$, Devanshi Magoo ${ }^{1}$ and ${ }^{*}$ Subhash Chandra ${ }^{2}$.

1. Department of Chemistry, University of Delhi, New Delhi-110007, India.

2. Custom House Laboratory, Custom House, Vasco-Da-Gama, Goa, India

\section{Manuscript Info}

\section{Manuscript History:}

Received: 12 May 2016

Final Accepted: 22 June 2016

Published Online: July 2016

Key words:

Urease Inhibitor, Barbiturate,

Imidazolidinone, Imidazolone, Jack

Bean Urease

*Corresponding Author

Subhash Chandra

\begin{abstract}
Based on the structural homology with urea, the substrate of urease, a variety of cyclic urea analogues viz. barbiturate, imidazolidinone and imidazolone derivatives were tested for their effect on jack bean urease in $50 \mathrm{mM}$ phosphate buffer, $\mathrm{pH}=7.0$. These compounds were found to inhibit jack bean urease in a concentration dependent manner $\mathrm{IC}_{50}$ varies from $0.6 \mathrm{mM}$ to $3.5 \mathrm{mM}$ with no further time dependent changes in the reaction velocities. Evaluation of the kinetic data from Lineweaver-Burk plots and Dixon plots revealed that the analyzed compounds act as reversibile competitive inhibitors of the plant enzyme.
\end{abstract}

\section{Introduction:-}

Urease (urea amidohydrolase; E.C.3.5.1.5) is a nickel containing enzyme that hydrolyses urea to form carbamate and ammonia; carbamate spontaneously degrades to $\mathrm{CO}_{2}$ and a second molecule of ammonia. ${ }^{1-3}$ The rate of the catalysed reaction is $10^{14}$ fold the rate of non-enzymic degradation.

$$
\mathrm{H}_{2} \mathrm{~N}-\stackrel{\mathrm{O}}{\mathrm{C}}-\mathrm{NH}_{2}+2 \mathrm{H}_{2} \mathrm{O} \longrightarrow 2 \mathrm{NH}_{4}^{+}+\mathrm{HCO}_{3}^{-}
$$

Ureases isolated from a wide range of sources including plants, bacteria and fungi although have different structure, number and type of subunits but have highly similar amino acid sequences at the active site and the mechanism of enzyme activity. ${ }^{3-6}$ The enzyme metallocenter contains two nickel ion, which are $3.5 \mathrm{~A}^{0}$ apart and liganded by three and four protein atoms respectively. This metallocenter is directly involved in binding of substrate and inhibitors. Urease is the primary enzyme responsible for enabling an organism to use urea as a source of nitrogen. It also acts as defense protein in systemic nitrogen transport pathways in plants. Apart from the advantages, recently the focus is shifted to its negative effects in agriculture, environment and medical. A recent topic is an urease in Helicobacter pylori, which is now accepted as a major cause of peptic ulcer. ${ }^{9}$ On the other hand, excessive ammonia released from urea based fertilizers by ureases from soil microbes, has been shown to adversely affect germination and seedling growth. ${ }^{7,8}$

All these findings emphasize upon the need to search for methods of reducing urease activity. An approach to diminish the negative effects of urease in human and animal health as well as in the agricultural environment involves designing of novel and potent inhibitors of the enzyme which would contribute towards reduction in environmental pollution and enhance the efficiency of urea nitrogen uptake by plants. Thereby, accentuating that the study of urease inhibition has medical, environmental and agronomic significance. Also the studies on urease inhibitors can provide insight into the detailed mechanism of catalysis particularly with competitive inhibitors. With the determination of high-resolution X-ray structures of native and inhibited ureases from bacillus pasteurii and klebsiella aerogenes, it is now possible to rationally search for the inhibitors. 
Thus are current efforts are focused on seeking novel urease inhibitors with good availability and low toxicity. Therefore we decided to study some heterocycles having urea moiety in their structure and which are easy to synthesise for substrate like or active site directed inhibitors. Our interest stem from the tremendous importance of barbiturates, thiobarbiturates, thiohydantoin, imidazolidones in synthetic organic chemistry and the use of these compounds as biological agents which may serve as lead for the development of therapeutic agents for the treatment of some disease. Barbituric acids are sedative drugs comprising a vast class of synthetic substances with closely related chemical structures and similar pharmacological activities. ${ }^{10}$ Their sodium salts are suitable for subcutaneous, intramuscular or intravenous injections. Therefore, the therapeutic values of these drugs are unquestioned. 2-Thiohydantoin are of particular interest because of their anticonvulsant and immunostimulant properties. ${ }^{11}$ Thiobarbituric acid derivatives are well known thyroid inhibitors and they are also used as anesthetics (intravenous). ${ }^{12}$ Further, 2-oxo- and 2-thioxo-1,3- $N$-heterocycles are interesting compounds from pharmaceutical point of view. In particular, the antibiotics SF-1993 ${ }^{13}$ and CV-1 14 are based on these core templates. The proposed inhibitors of urease could be derived based on the structural homology with urea (Fig.1).<smiles>[X]C1NC(=O)C([R])([R])C(=O)N1</smiles>

Barbiturates / Thiobarbiturates<smiles>[X]C1NC(=O)C([R])N1</smiles>

Hydantoins/ Thiohydantoins<smiles></smiles>

1,3-Dihydrobenzoimidazol-2-ones /

1,3-Dihydrobenzoimidazole-2-thiones<smiles>S=C1NCCN1</smiles>

Imidazolidine-2-thione

$$
\mathrm{R}=\mathrm{H} \text {, alkyl, aryl; } \mathrm{X}=\mathrm{O}, \mathrm{S}
$$

\section{Materials and Methods:- \\ Materials:-}

Fig. 1

Jack bean urease with defined specific activity (Type III) was purchased from Sigma St. Louis, USA. Urea, used as the enzyme substrate, was purchased from E. Merck, India. Barbituric acid, thiobarbituric acid and thiourea were purchased from Spetrochem, India. 5,5-Dimethylbarbituric acid, 1,3-dimethyl barbituric acid, 5,5-dibromobarbituric acid, 5-nitrobarbituric acid, urazole and parabanic acid were purchased from Sigma Aldrich, Steinheim, Germany. 2Thiohydantoin was purchased from Sigma Aldrich, USA. 1,3-Diphenyl barbituric acid, 1,3-diphenyl-2thiobarbituric acid, 5-phenyl barbituric acid, 5-phenyl-2-thiobarbituric acid, 1,3,5-triphenyl-2-thiobarbituric acid, 1,3-di(p-tolyl)-2-thiobarbituric acid, 1,3-di(p-anisyl)-2-thiobarbituric acid, 1,3-di(p-chlorophenyl)-2-thiobarbituric acid were synthesized by the condensation of malonic acid and substituted malonic acids with the corresponding ureas and thioureas respectively as reported. ${ }^{15}$ 5-Acetyl barbituric acid and 5-acetyl-2-thiobarbituric acid were prepared by the acetylation of corresponding barbiturates as reported. ${ }^{16} 5$-Benzylbarbituric acid was prepared by the benzylation of barbituric acid as reported. ${ }^{17}$ Hydantoin was prepared by the condensation of urea with chloroacetic acid as reported. ${ }^{18}$ 1-Methyl-5-benzyl-2-thiohydantoin was prepared by the reaction of methylamine, carbon disulphide, triethyl amine, iodomethane and phenylalanine under reflux as published. ${ }^{19}$ 1,3-Dihydrobenzimidazol-2thione was prepared from o-phenylenediamine and $\mathrm{CS}_{2}$ by the known procedure. ${ }^{20}$ Imidazolidine-2-thione was 
synthesized by reaction of ethane-1,2-diamine and $\mathrm{CS}_{2}$ as per the reported procedure. ${ }^{21}$ All other chemicals used were of analytical grade.

\section{Methods:-}

Urease activity measurements:-

The enzyme used in the current study has a specific activity of 15-19 Units $\mathrm{mg}^{-1}$ protein (varied from batch to batch). One unit is the amount of enzyme that liberates $1.0 \mu \mathrm{mol}$ of $\mathrm{NH}_{3}$ from urea per minute at $\mathrm{pH} 7.0$ and $37{ }^{\circ} \mathrm{C}$. All activity measurements were done in triplicate. The activity was determined by measuring ammonia liberated on incubation of urease with enzyme saturating concentration of urea $(100 \mathrm{mM}$ urea) for a fixed time period of 5 minutes using the colorimetric phenol-hypochlorite method. ${ }^{22}$ The blue colour obtained was measured spectrophotometrically at $630 \mathrm{~nm}$ (ELICO CL 157 colorimeter).

\section{Protein estimation:-}

Protein was assayed by the method of Lowry et al. ${ }^{23}$ with bovine serum albumin as the standard.

\section{Inhibition Studies:-}

Stock solutions of inhibitors were prepared in $50 \mathrm{mM}$ phosphate buffer ( $25 \mathrm{mM} \mathrm{NaCl}, 1 \mathrm{mM}$ EDTA), pH 7.0 and were suitably diluted for the experiments. The solutions of 1,3-diphenyl barbituric acid, 1,3-diphenyl-2thiobarbituric acid, 1,3-dihydrobenzimidazol-2-thione, 1,3-dihdrobenzimidazol-2-one were prepared in phosphate buffer using DMF as the co-solvent.

\section{Determination of $\mathrm{IC}_{\mathbf{5 0}}$ :-}

Residual activity of jack bean urease $\left(\mathrm{pH} 7.0\right.$, in phosphate buffer, $100 \mathrm{mM}$ urea) at $37{ }^{\circ} \mathrm{C}$ was assayed in the presence of test compounds $(0.01 \mathrm{mM}$ to $10 \mathrm{mM}) . \mathrm{IC}_{50}$ values of different inhibitors were obtained from the dose response curves. Thiourea was taken as the standard inhibitor of urease $\left(\mathrm{IC}_{50}=2.1 \mathrm{mM}\right)$.

\section{Time dependent study of inhibition:-}

Urease and test compound (fixed concentration) were preincubated at $37^{\circ} \mathrm{C}$. After fixed time intervals ranging from 5-300 min, urea (100 mM) was added. After $5 \mathrm{~min}$ of reaction, the liberated ammonia was measured by colorimetric phenol-hypochlorite method. ${ }^{22}$ Kinetic curves were obtained by plotting residual activity against time.

\section{Determination of $K_{m}$ and $V_{\text {max }}$ :-}

The Michaelis constant $\mathrm{K}_{\mathrm{m}}$ and the maximum velocity $\mathrm{V}_{\max }$ in the absence of inhibitors were determined by measuring the initial reaction velocities at different urea concentrations in the range of 2-200 mM. Data were plotted according to Lineweaver and Burk. ${ }^{\text {ref }}$ At $\mathrm{pH}=7.0$ and $37^{\circ} \mathrm{C}, \mathrm{K}_{\mathrm{m}} \approx 3.40$ and $\mathrm{V}_{\max } \approx 0.113 \mu \mathrm{M} \mathrm{min}{ }^{-1}$.

\section{Determination of $\mathbf{K}_{\mathrm{i}}$ :-}

The initial velocities were determined at varying concentrations of the inhibitors at each of the three urea concentrations $(10,50$ and $100 \mathrm{mM})$. Inhibition constants $\left(\mathrm{K}_{\mathrm{i}}\right)$ were determined from Dixon plots. ${ }^{\text {ref }} \mathrm{K}_{\mathrm{i}}$ values were also determined from replots of slope or apparent $\mathrm{K}_{\mathrm{m}}$ values versus inhibitor concentration. ${ }^{\text {ref }}$

\section{Inhibition studies at different pH:-}

Residual activity of urease in the presence of barbituric acid and thiobarbituric acid was determined at different $\mathrm{pH}$ (5.3-8.5) in phosphate and citrate buffers in presence of urea $(100 \mathrm{mM})$. Residual activity of these test compounds was also determined in millipore water. Effect of $\mathrm{pH}$ on inhibitory activity of test compounds was deciphered from the plots of residual activity versus $\mathrm{pH}$.

\section{Results and Discussion:-}

\section{Residual activity $\left(\mathrm{IC}_{50}\right)$ :-}

Since JBU is the most widely studied enzyme and is found to have $<50 \%$ homology in its sequence with the other known ureases (Klebsiella aerogeges, H. pylori, etc.) It has been chosen as the model system. The $\mathrm{IC}_{50}$ values of various inhibitors is obtained from the dose response curves at increasing concentration $(0.01 \mathrm{mM}$ to $10 \mathrm{mM})$ of test compounds and are listed in Table 1. The compounds exhibited varying degree of enzyme inhibitory activity with the $\mathrm{IC}_{50}$ values ranging from $0.63 \mathrm{mM}$ to $9 \mathrm{mM}$. Compared to the standard inhibitor thiourea $(\mathrm{IC} 50=2.1 \mathrm{mM}), 2-$ thiobarbituric acid $(0.8 \mathrm{mM})$, 5-phenyl barbituric acid (1.8 $\mathrm{mM})$, 1,3-diphenyl barbituric acid(1.6 mM), 2thiohydantoin $(1.1 \mathrm{mM}), 1,3$-dihydrobenzimidazol-2-thione $(1.4 \mathrm{mM})$ and imidazolidine-2-thione $(0.63 \mathrm{mM})$ were 
found to be more potent inhibitors of jack bean urease as per the $\mathrm{IC}_{50}$ data. With hydantoin (19) and parabanic acid (27) no inhibition was observed.

Table 1:- Inhibition concentration $\left(\mathrm{IC}_{50}\right)$ of various inhibitors for urease at $\mathrm{pH} 7.0,37^{\circ} \mathrm{C}$ in phosphate buffer urea (100 mM)

\begin{tabular}{|c|c|c|}
\hline & Inhibitor & $\mathrm{IC}_{50}(\mathrm{mM})$ \\
\hline 1 & Thiourea (standard) & 2.1 \\
\hline 2 & Barbituric acid & 2.3 \\
\hline 3 & 2-Thiobarbituric acid & 0.8 \\
\hline 4 & 5-Acetyl barbituric acid & 5.0 \\
\hline 5 & 5-Acetyl-2-thiobarbituric acid & N.D ${ }^{\mathrm{a}}$ \\
\hline 6 & 5-Phenyl barbituric acid & 1.8 \\
\hline 7 & 5-Phenyl-2-thiobarbituric acid & N.D. ${ }^{\mathrm{a}}$ \\
\hline 8 & 1,3-Diphenyl barbituric acid & 1.6 \\
\hline 9 & 1,3-Diphenyl-2-thiobarbituric acid & 3.5 \\
\hline 10 & 1,3-di(p-Tolyl)-2-thiobarbituric acid & N.D. ${ }^{a}$ \\
\hline 11 & 1,3-di(p-Anisyl)-2-thiobarbituric acid & N.D. ${ }^{a}$ \\
\hline 12 & 1,3-di(p-Chlorophenyl)-2-thiobarbituric acid & N.D. ${ }^{a}$ \\
\hline 13 & 5-Benzyl barbituric acid & $>7.0$ \\
\hline 14 & 1,3,5-Triphenyl barbituric acid & N.D. ${ }^{a}$ \\
\hline 15 & 1,3-Dimethyl barbituric acid & $>9.0 \mathrm{mM}$ \\
\hline 16 & 5,5-Dimethyl barbituric acid & N.D. ${ }^{b}$ \\
\hline 17 & 5-Nitro barbituric acid & N.D. ${ }^{b}$ \\
\hline 18 & 5,5-Dibromo barbituric acid & N.D. ${ }^{b}$ \\
\hline 19 & Imidazolidine-2,4-dione (hydantoin) & No Inhibition observed \\
\hline 20 & 2-Thioxo-imidazolidin-4-one (2-thiohydantoin) & 1.1 \\
\hline 21 & 5-Benzyl-3-methyl-2-thioxo-imidazolidin-4-one & N.D. ${ }^{a}$ \\
\hline 22 & 5,5-Diphenyl-2-thioxo-imidazolidin-4-one & N.D. ${ }^{a}$ \\
\hline 23 & 1,3-Dihydrobenzimidazol-2-thione & 1.4 \\
\hline 24 & 1,3-Dihydrobenzimidazol-2-one & $>6.0$ \\
\hline 25 & Imidazolidine-2-thione & 0.63 \\
\hline 26 & Urazole & N.D. ${ }^{b}$ \\
\hline 27 & Parabanic acid & No Inhibition observed \\
\hline
\end{tabular}

a: Not determined (N.D.) because of solubility limitations

b: Not determined (N.D.) because of interference with the assay

After preliminary studies of the of the $\mathrm{IC}_{50}$ values, detailed kinetic studies were pursued for barbituric acid, 2thiobarbituric acid (2), 5-acetyl barbituric acid (4), 5-phenyl barbituric acid (6), 1,3-diphenyl barbituric acid (8), 1,3diphenyl-2-thiobarbituric acid (9), 2-thiohydantoin (20), 1,3-dihydrobenzimidazol-2-thione (23), imidazolidine-2thione (25).

\section{Time dependent study of inhibition:-}

The reversible or irreversible nature of inhibition can be determined by pre-incubation of the enzyme with the inhibitor. For reversible inhibition, pre-incubation of enzyme and inhibitor has no effect on the activity of the enzyme while for irreversibile inhibition; the loss of enzyme activity is proportional to the preincubation time. To determine the nature of inhibition exhibited by these inhibitors, inhibitory activity of the test compounds was studied with time by assaying the residual activity. The plots of residual activity at fixed inhibitor concentration versus time (Fig. 2) suggested that inhibition is independent of enzyme-inhibitor incubation time at the concentrations tested. No further time dependent changes have been observed in the reaction velocity which indicates that these compounds are fast binding inhibitors of jack bean urease. 
The inhibition is reversible because when urea $(100 \mathrm{mM})$ was added, it displaced the inhibitor as confirmed by phenolhypochlorite assay. Even if urease is pre-incubated with these inhibitors for longer time $(5 \mathrm{~h})$, as soon as the urea was added in saturated conditions $(100 \mathrm{mM})$, the activity of urease was regained, thus confirming the reversible nature of inhibition.

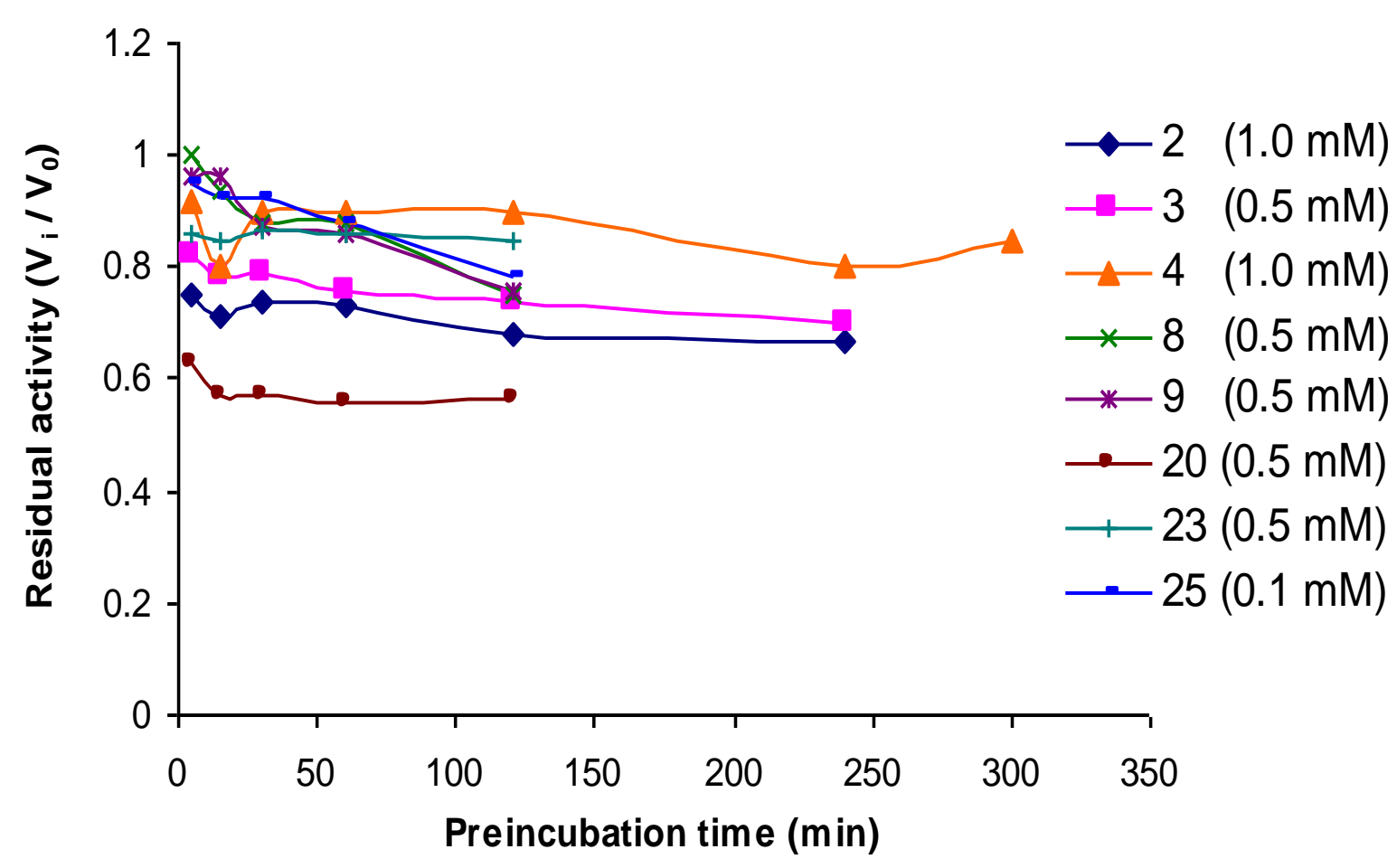

Fig. 2:- Time course of inhibition of jack bean urease by cyclic urea analogues

Determination of $K_{M}$ and $V_{\text {max }}$ :-

The kinetic parameters of urease inhibition at $\mathrm{pH} 7.0$ were determined at concentrations of the inhibitors ranging from $0.1 \mathrm{mM}$ to $2 \mathrm{mM}$. The $\mathrm{K}_{\mathrm{m}}$ values in the absence of inhibitors were in the range $3.12-3.85 \mathrm{mM}$ while in their presence, the $\mathrm{K}_{\mathrm{m}}$ increased in a concentration dependent manner from 4.76 to $20 \mathrm{mM}$. The test compounds caused no change on $\mathrm{V}_{\max }$ having values around $0.0069-0.0282 \mu \mathrm{mol} \mathrm{min}{ }^{-1}$. The $\mathrm{K}_{\mathrm{m}}$ and $\mathrm{V}_{\max }$ values in the absence of inhibitor, $\mathrm{K}_{\mathrm{m}}^{\text {app }}$ and $\mathrm{V}_{\max }$ app in the presence of inhibitors as calculated from Lineweaver-Burk (Figs. 3A, 3B) and Michaelis-Menten (Fig. 3 insets) plots have been summarized in Table 2. 
Table 2:- Kinetic parameters of jack bean urease $\left(\mathrm{pH} 7.0,37^{\circ} \mathrm{C}\right)$ in the presence of cyclic urea analogues as inhibitors.

\begin{tabular}{|c|c|c|c|c|c|}
\hline Inhibitor & $\begin{array}{c}\mathrm{K}_{\mathrm{m}} \\
(\mathrm{mM})\end{array}$ & $\begin{array}{l}\mathrm{K}_{\mathrm{m}}^{\mathrm{app}} \\
(\mathrm{mM})\end{array}$ & $\begin{array}{c}\mathrm{V}_{\max } \\
(\mu \mathrm{mol} / \mathrm{min})\end{array}$ & $\begin{array}{c}\mathrm{V}_{\max }{ }^{\text {app }} \\
(\mu \mathrm{mol} / \mathrm{min})\end{array}$ & $\begin{array}{c}\mathrm{K}_{\mathrm{i}} \\
(\mathrm{mM})(\text { mean })\end{array}$ \\
\hline 2 & 3.85 & $\begin{array}{l}6.25(0.2 \mathrm{mM}) \\
8.33(0.5 \mathrm{mM}) \\
11.11(0.8 \mathrm{mM})\end{array}$ & 0.0108 & $\begin{array}{l}0.0104(0.2 \mathrm{mM}) \\
0.0104(0.5 \mathrm{mM}) \\
0.0108(0.8 \mathrm{mM})\end{array}$ & 0.78 \\
\hline 3 & 3.33 & $\begin{array}{l}7.14(0.5 \mathrm{mM}) \\
11.11(1.0 \mathrm{mM})\end{array}$ & 0.0282 & $\begin{array}{c}0.0266(0.5 \mathrm{mM}) \\
0.0264(1.0 \mathrm{mM})\end{array}$ & 0.40 \\
\hline 4 & 3.44 & $\begin{array}{l}5.00(1.0 \mathrm{mM}) \\
9.09(2.0 \mathrm{mM})\end{array}$ & 0.0094 & $\begin{array}{l}0.0095(1.0 \mathrm{mM}) \\
0.0101(2.0 \mathrm{mM})\end{array}$ & 1.16 \\
\hline 6 & 3.6 & $\begin{array}{l}5.55(0.1 \mathrm{mM}) \\
6.67(0.2 \mathrm{mM}) \\
7.14(0.5 \mathrm{mM})\end{array}$ & 0.0136 & $\begin{array}{l}0.0126(0.1 \mathrm{mM}) \\
0.0129(0.2 \mathrm{mM}) \\
0.0140(0.5 \mathrm{mM})\end{array}$ & 0.53 \\
\hline 8 & 3.33 & $\begin{array}{l}4.76(0.2 \mathrm{mM}) \\
8.33(0.5 \mathrm{mM}) \\
9.09(1.0 \mathrm{mM})\end{array}$ & 0.0095 & $\begin{array}{l}0.0097(0.2 \mathrm{mM}) \\
0.0104(0.5 \mathrm{mM}) \\
0.0103(1.0 \mathrm{mM})\end{array}$ & 0.78 \\
\hline 9 & 3.12 & $\begin{array}{l}7.14(0.5 \mathrm{mM}) \\
10.00(1.0 \mathrm{mM})\end{array}$ & 0.0084 & $\begin{array}{l}0.0089(0.5 \mathrm{mM}) \\
0.0090(1.0 \mathrm{mM})\end{array}$ & 0.56 \\
\hline 20 & 3.33 & $\begin{array}{l}5.00(0.2 \mathrm{mM}) \\
5.88(0.5 \mathrm{mM}) \\
10.00(1.0 \mathrm{mM})\end{array}$ & 0.0160 & $\begin{array}{l}0.0168(0.2 \mathrm{mM}) \\
0.0169(0.5 \mathrm{mM}) \\
0.0162(1.0 \mathrm{mM})\end{array}$ & 0.50 \\
\hline 23 & 3.33 & $\begin{array}{l}5.00(0.5 \mathrm{mM}) \\
11.11(1.0 \mathrm{mM}) \\
16.66(2.0 \mathrm{mM})\end{array}$ & 0.0102 & $\begin{array}{l}0.0101(0.5 \mathrm{mM}) \\
0.0110(1.0 \mathrm{mM}) \\
0.0109(2.0 \mathrm{mM})\end{array}$ & 0.51 \\
\hline 25 & 3.33 & $\begin{array}{l}7.69(0.3 \mathrm{mM}) \\
20.00(0.5 \mathrm{mM})\end{array}$ & 0.0069 & $\begin{array}{l}0.0068(0.3 \mathrm{mM}) \\
0.0070(0.5 \mathrm{mM})\end{array}$ & 0.058 \\
\hline
\end{tabular}

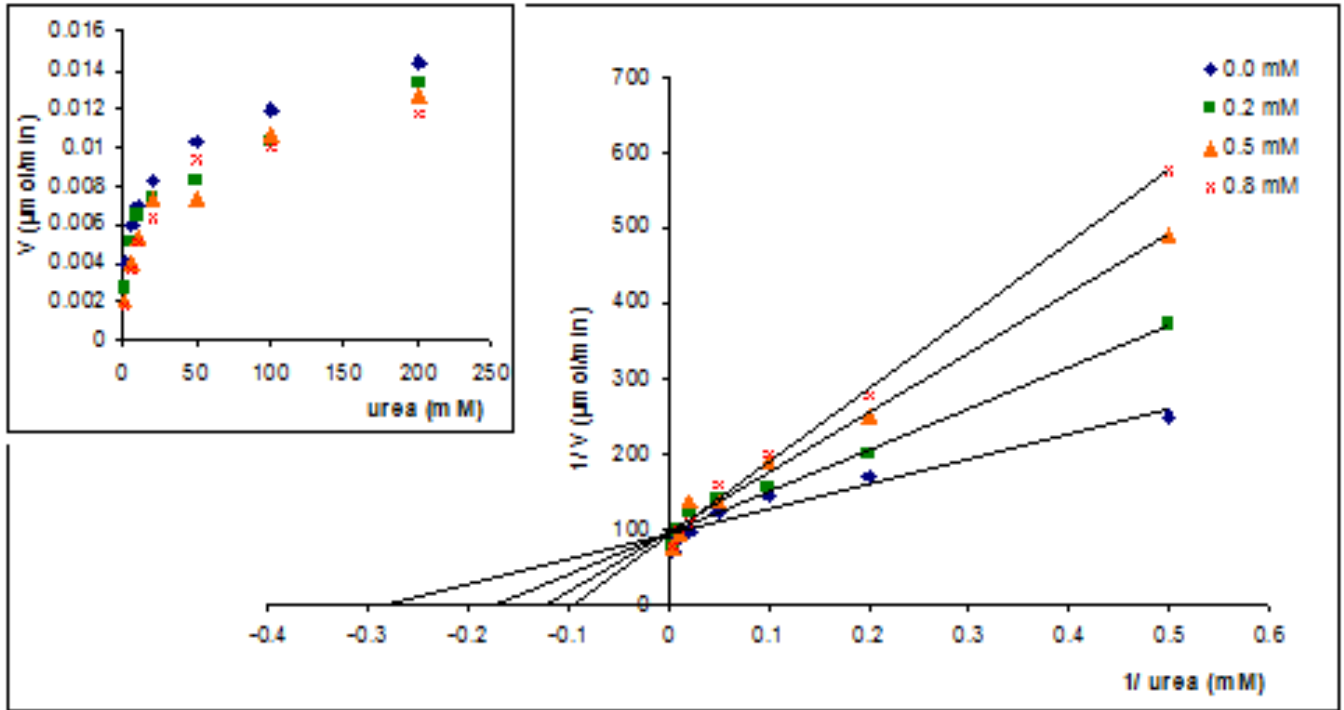

Fig. 3A:- Lineweaver-Burk plot representing reciprocal of initial enzyme velocity versus reciprocal of urea concentration in the absence and presence of $\mathbf{2}$ (barbituric acid; concentrations indicated in the legend box) at $\mathrm{pH}$

7.0. Inset shows the Michaelis-Menten plot for 2. 


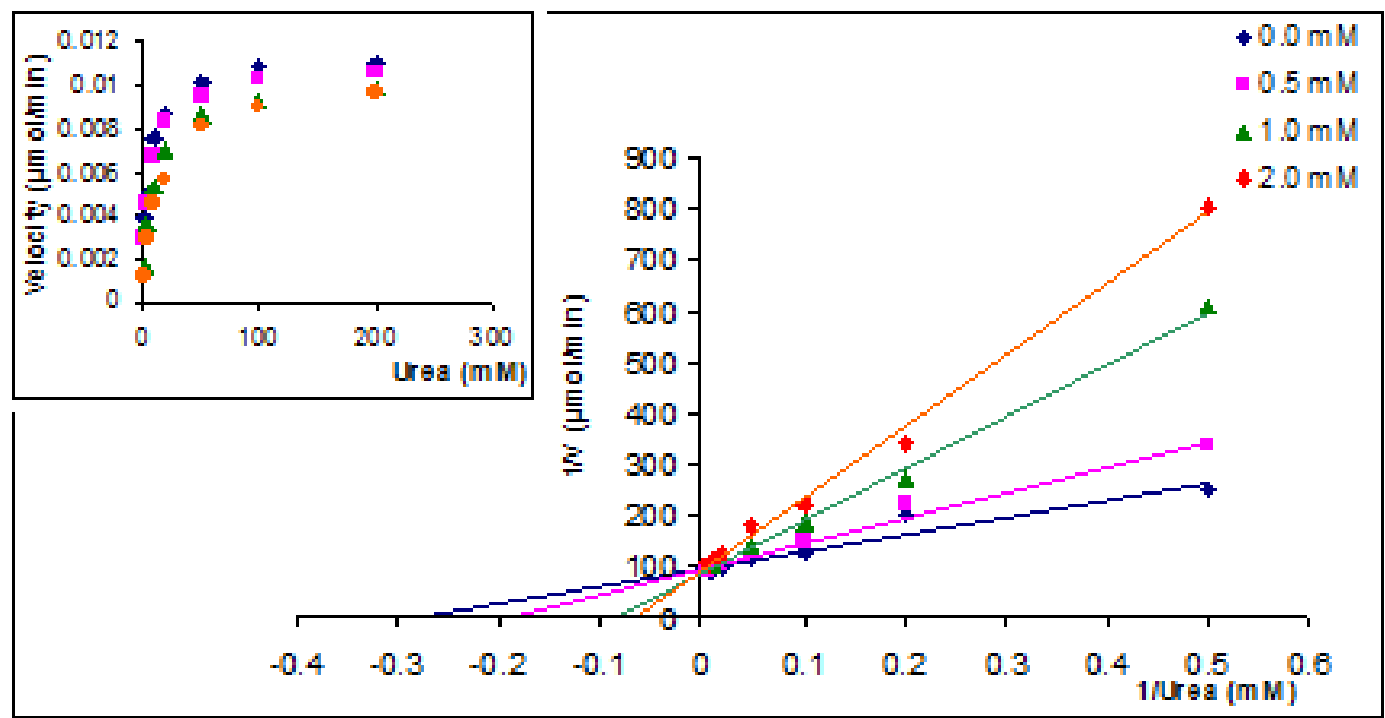

Fig. 3B:- Lineweaver-Burk plot representing reciprocal of initial enzyme velocity versus reciprocal of urea concentration in the absence and presence of $\mathbf{2 3}$ (barbituric acid; concentrations indicated in the legend box) at $\mathrm{pH}$ 7.0. Inset shows the Michaelis-Menten plot for $\mathbf{2 3}$.

The increase in $\mathrm{K}_{\mathrm{m}}$ without affecting the $\mathrm{V}_{\max }$ in the presence of tested inhibitors indicates the competitive nature of inhibition by these inhibitors. As expected, therefore the degree of inhibition depends on the substrate concentration. Decreasing the substrate concentration increased the degree of inhibition as can be seen from the residual activity plot (Fig. 4A) for 5-acetyl barbituric acid (4). The $\mathrm{IC}_{50}$ for 4 decreased from $5 \mathrm{mM}$ to $3.9 \mathrm{mM}$ to $2.1 \mathrm{mM}$ as the substrate concentration was decreased from $100 \mathrm{mM}$ to $50 \mathrm{mM}$ to $10 \mathrm{mM}$.

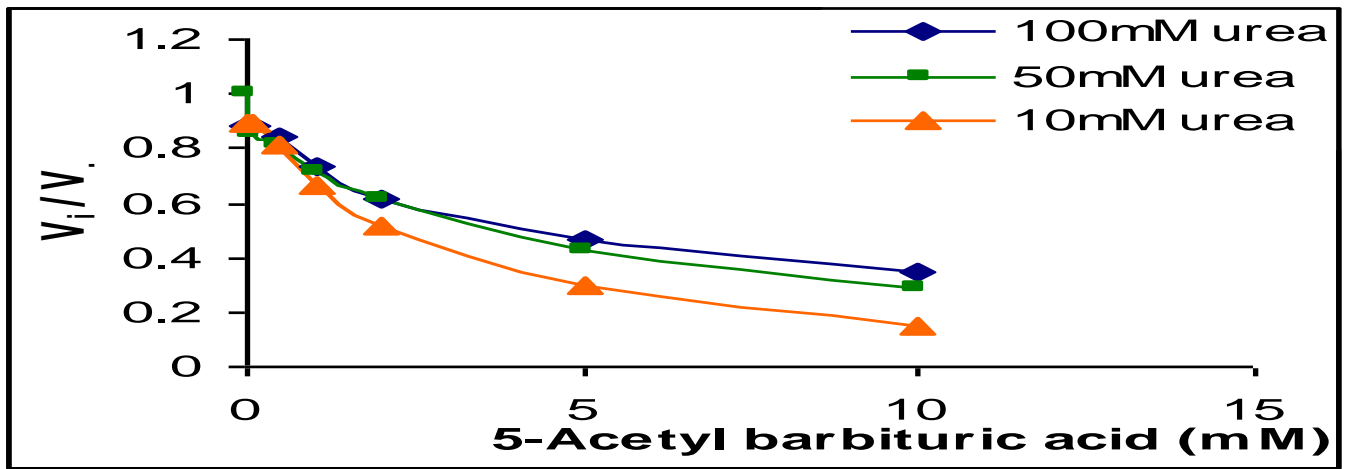

Fig. 4:- Effect of urea concentration on $\mathrm{IC}_{50}$ values of $4 . \mathrm{V}_{\mathrm{i}}$ and $\mathrm{V}_{0}$ are initial enzyme velocities in the presence and

Inhibition constant $\left(\mathbf{K}_{\mathbf{i}}\right)$ :absence of 4 .

$\mathrm{K}_{\mathrm{i}}$ (dissociation/ inhibition constant of the urease-inhibitor complex into free urease and inhibitor) for different inhibitors was determined by three ways. First, the slopes of each line in the LWB were plotted against concentrations of different inhibitors. Secondly, the $\mathrm{K}_{\mathrm{m}}{ }^{\text {app }}$ was calculated at each concentration of inhibitor and then plotted against inhibitor concentrations and then $\mathrm{K}_{\mathrm{i}}$ was calculated from the intercepts on the x-axis (Fig. 5 insets). In the third method $\mathrm{K}_{\mathrm{i}}$ values were determined by assaying urease activity at fixed concentrations $(10,50,100 \mathrm{mM})$ of urea in the presence of different concentrations of inhibitors. $\mathrm{K}_{\mathrm{i}}$ values were determined directly from the intersections of the line for each substrate concentration on the $\mathrm{x}$-axis by the Dixon plots (reciprocal of initial enzyme velocity versus inhibitor concentration, Figs. 5A, 5B). 

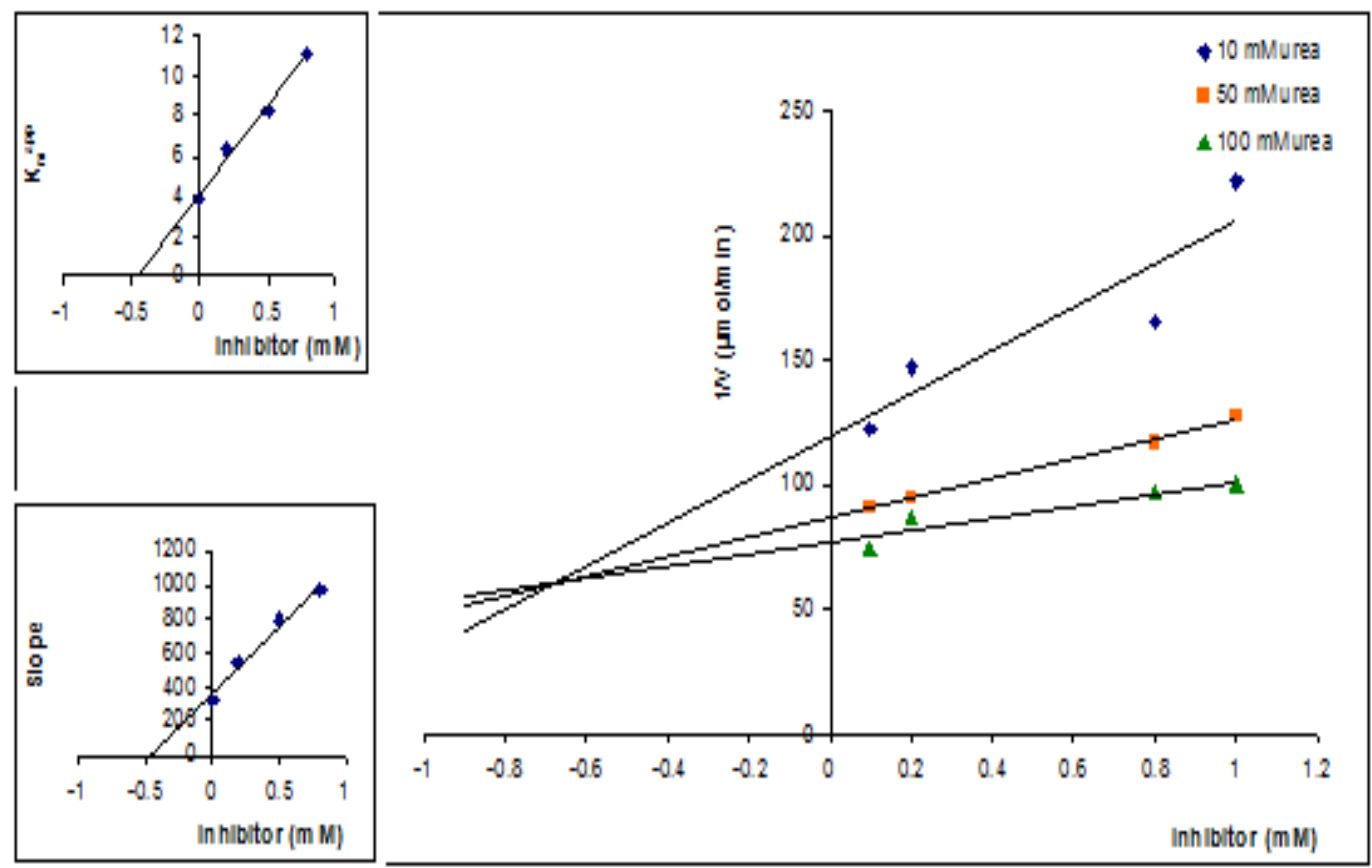

Fig. 5A:- Dixon plot for barbituric acid (2) representing reciprocal of initial enzyme velocity versus inhibitor concentration at fixed urea concentrations $(10,50,100 \mathrm{mM})$. Insets show the secondary replots of LWB plots i.e., $\mathrm{K}_{\mathrm{m}}{ }^{\text {app }}$ and slopes versus inhibitor concentrations for 2 . The $\mathrm{K}_{\mathrm{i}}$ reported is the mean value obtained from these three plots.
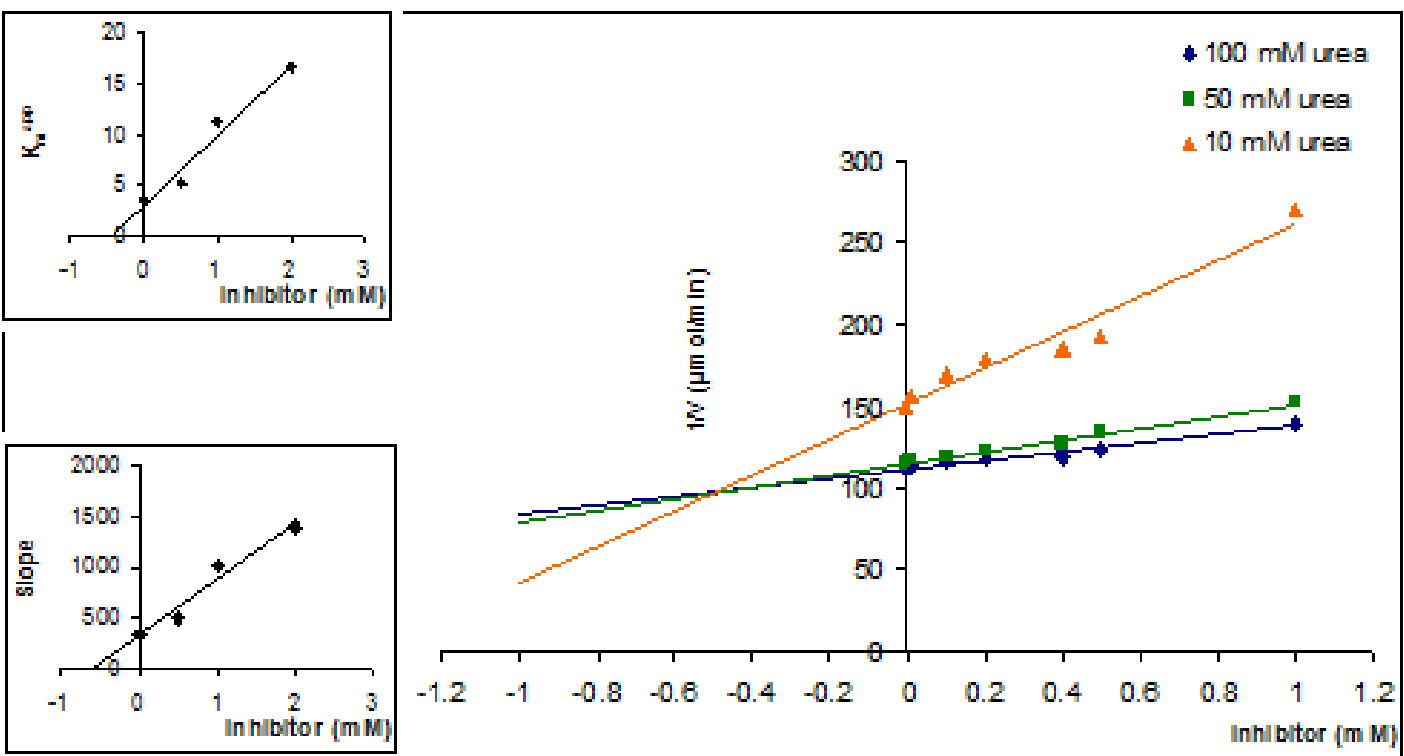

Fig. 5B:- Dixon plot for 1,3-dihydrobenzimidazol-2-thione (23) representing reciprocal of initial enzyme velocity versus inhibitor concentration at fixed urea concentrations $(10,50,100 \mathrm{mM})$. Insets show the secondary replots of LWB plots i.e., $\mathrm{K}_{\mathrm{m}}{ }^{\text {app }}$ and slopes versus inhibitor concentrations for $\mathbf{2 3}$. The $\mathrm{K}_{\mathrm{i}}$ reported is the mean value obtained from these three plots.

It can be inferred from the results of mean $\mathrm{K}_{\mathrm{i}}$ drawn in Table 2 that among the barbituric acid derivatives analysed, 1,3-diphenyl barbituric acid $(0.78 \mathrm{mM})$ and 1,3-diphenyl-2-thiobarbituric acid $(0.56 \mathrm{mM})$, which have hydrophobic phenyl groups, are more potent inhibitors of urease as compared to 5-acetyl barbituric acid $(1.16 \mathrm{mM})$. This behavior can be explained on the basis of the fact that the active site of urease is surrounded by some hydrophobic amino acid residues. The presence of hydrophobic groups in the tested compounds assists in the random walk 
process of the compounds to the active site facilitating the binding of hydrophobic moieties near the active site. The same argument, however, may not hold true for 1,3-dihydrobenzimidazol-2-thione $(0.51 \mathrm{mM})$ and its alicyclic analogue imidazolidine-2-thione (0.058). A reasonable explanation to this can be given by taking into consideration the small size and greater structural homology of imidazolidine-2-thione with urea which allows it to easily get accommodated in the small urea binding pocket and hence exhibits maximum potency.

Examination of the kinetic data obtained from Lineweaver-Burk plots and Dixon plots indicates that the proposed inhibitors i.e. barbiturates imidazolidinone and imidazolone derivatives are in direct competition with the substrate, urea and show a competitive inhibition profile. The substrate binding pocket being small, the enzyme is unable to simultaneously bind to urea and to the inhibitor. The following mechanism for inhibition is proposed based on a literature survey and our observations (Scheme 1).

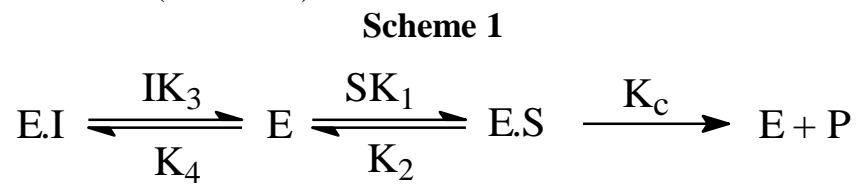

$\mathrm{E}=$ Enzyme, $\mathrm{S}=$ Substrate, $\mathrm{I}=$ Inhibitor, E.I = Enzyme-Inhibitor Complex, E.S = Enzyme-Substrate Complex, $\mathrm{P}=$ Product, $\mathrm{K}_{1}=$ Rate constant for the formation of ES complex, $\mathrm{K}_{2}=\mathrm{Rate}$ constant for the dissociation of ES complex, $\mathrm{K}_{3}=$ Rate constant for the formation of E.I complex, $\mathrm{K}_{4}=\mathrm{Rate}$ constant for the dissociation of E.I complex, $\mathrm{K}_{\mathrm{c}}=$ Rate constant for E.S dissociation and $\mathrm{K}_{\mathrm{i}}$ or $\mathrm{K}_{4} / \mathrm{K}_{3}=\mathrm{Enzyme}$ inhibitor equilibrium dissociation constant.

Competitive nature of inhibition exhibited by the tested compounds suggests that these compounds tend to bind to urease in substrate or active site directed mode such that the nickel atoms and the surrounding amino acid residues in the active site are in an orientation similar to that when binding the substrate i.e. urea (Scheme 2). The observed mode of inhibition could be due to the presence of part urea moiety in these inhibitors. These inhibitors can be classified as the cyclic urea derivatives. Further, the low $\mathrm{IC}_{50}$ and $\mathrm{K}_{\mathrm{i}}$ values of these inhibitors under saturating substrate concentration (100 $\mathrm{mM}$ urea) suggest that these compounds have very high affinity for urease as compared to the substrate (urea). This could be due to the presence of more $>C=O$ groups in $2,3,4,6,8,9,13,15,20$, which can involve in H-bonding with other amino acid residues surrounding the active site. Also the $\pi$ - $\pi$ stacking interactions between aromatic groups present in the inhibitors 21, 24, 8, 9 and aromatic amino acid residues in the enzyme help in stabilizing the transition state for the formation of E.I. complex (Scheme 2)

\section{Scheme 2}
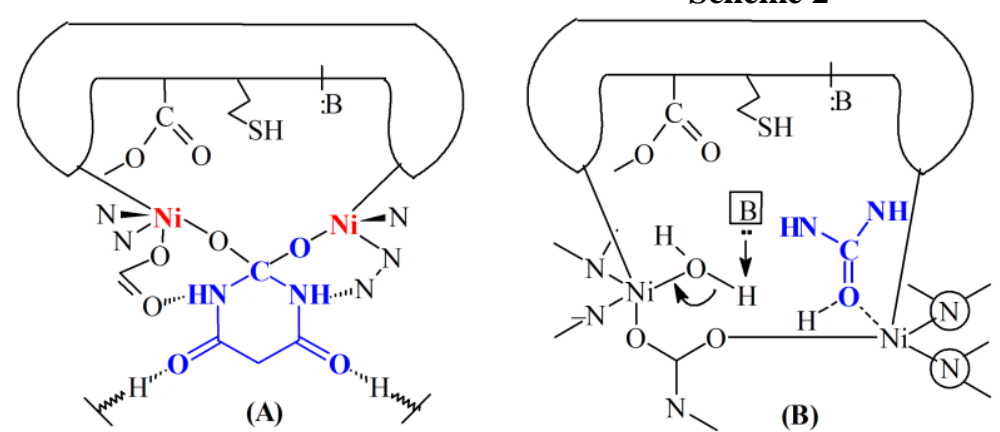

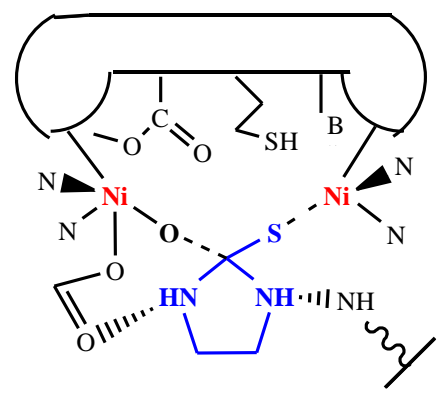

(C)

(A) Proposed binding of barbituric acid at the active site of urease; (B) Binding of urea; (C) Proposed binding of imidazolidine derivative at the active site of urease

Scheme 2 depicts that in the binuclear Ni center of hydrolytic enzyme both Ni ions are ligated by nitrogen atoms of four His imidazoles, a $\mathrm{COO}^{-}$group of the carbonylated Lys residue, and another $\mathrm{COO}^{-}$group from an Asp residue and one $\mathrm{H}_{2} \mathrm{O}$ molecule.

\section{Conclusion:-}

Thus it can be concluded that barbituric acid, 2-thiobarbituric acid, 5-acetyl barbituric acid, 5-phenyl barbituric acid, 1,3-diphenyl barbituric acid, 1,3-diphenyl-2-thiobarbituric acid, 2-thioxo-imidazolidin-4-one (2-thiohydantoin), 1,3dihydrobenzimidazol-2-thione and imidazolidine-2-thione inhibit jack bean urease in a concentration dependent manner. These compounds result in immediate inhibition of urease activity, with no further time-dependent changes in the reaction velocities suggesting that each of these compounds is a fast-binding, reversible inhibitor of the plant 
enzyme. Evaluation of the kinetic data reveals that these novel inhibitors act in a competitive fashion by mimicking the substrate transition state and have homologous mechanism of action as they tend to bind at the binuclear active site of enzyme in an orientation - specific mode. These inhibitors and other similar compounds may provide useful probes for the study of the active site of urease and other hydrolytic enzymes. Their catalytic activity, intimate details of the molecular geometry at the active-site and the kinetics of the binding site of the urease will provide new template structures for the design of more potent inhibitors with an optimized pharmacological profile.

\section{References:-}

1. Andrews RK, Blakeley RL, Zerner B. In: Eichhorn BL, Marzilli LG, eds. Advances in Inorganic Biochemistry. New York: Elsevier Science Publishing Co. Inc.;1984:245-83.

2. Blakely R, Zerner B. Jack bean urease: the first nickel enzyme. J Mol Catal 1984; 23:263-92.

3. Mobley HL, Hausinger RP. Microbial ureases: significance, regulation and molecular characterization. Microbiol Rev 1989; 53:85-108.

4. Blakely RL, Hinds JA, Kunze HE, Webb EC, Zerner B. Jack bean urease (EC 3.5.1.5). Demonstration of a carbamoyl-transfer reaction and inhibition by hydroxamic acids. Biochemistry 1969;8: 1991-2000.

5. Mobley HL, Island MD, Hausinger RP. Molecular biology of microbial ureases. Microbiol Rev 1995;59:45180 .

6. Sirko A, Brodzik R. Plant ureases: roles and regulation. Acta Biochim Pol 2000; 47:1189-95.

7. Bremner JM, Krogmeier MJ. Elimination of the adverse effects of urea fertilizer on seed germination, seedling growth, and early plant growth in soil. Proc Natl Acad Sci USA 1988;85: 4601-04.

8. Bremner JM, Krogmeier MJ. Evidence that the adverse effect of urea fertilizer on seed germination in soil is due to ammonia formed through hydrolysis of urea by soil urease. Proc Natl Acad Sci USA 1989; 86:8185-88.

9. Marshall BJ, Mc Gechie DB, Rogers PA, Glancy RJ. Pyloric campylobacter infection and gastroduodenal disease. Med J Aust 1985; 142:439-44.

10. [10](a) Baeyer A. Untersuchungen über die harnsäuregruppe. Ann der Chemie und Pharmcie 1863;127:199236.

11. Baeyer A. Mittheilungen aus dem organischen laboratorium des Gewerbeinstitutes in Berlin: Untersuchungen über die harnsäuregruppe. Ann Ann der Chemie und Pharmcie 1864;130:129-75.

12. Carter MK. The story of barbituric acid. J Chem Ed 1951;28:524-26.

13. Goldenthal EI. A compilation of LD50 values in newborn and adult animals. Toxicol Appl Pharmacol 1971;18:185-207.

14. Lopez CA, Trigo GG. The chemistry of hydantoins. Adv Hetero Chem 1985;38:177-228. (b) Hess HJ, Cronin TH, Scriabine A. Antihypertensive 2-amino-4(3H)-quinazolinones. J Med Chem 1968;11:130-36.

15. Saija A, Scalese M, Lanza M, Marzullo D, Bonina F, Castelli F. Flavonoids as antioxidant agents: importance of their interaction with biomembranes. Free Radical Biol Med 1995;19:481-86.

16. Omoto S, Shomura T, Suzuki H, Inouye S. Studies on Actinomycetales producing antibiotics only on agar culture. II. Isolation, structure and biological properties of N-carbamoyl-D-glucosamine (substance SF-1993). J Antibiotic 1979;32:436-41.

17. Yasuzawa T, Yoshida M, Ichinmura M. CV-1, a new antibiotic produced by a strain of Streptomyces sp.II. Structure determination. J Antibiotic 1987;40:727-31.

18. Vogel AI. Textbook of Practical Organic Chemistry. Oxford:ELBS, 1987:1001.

19. Jursic BS, Neumann DM. Preparation of 5-formyl- and 5-acetylbarbituri acids, includig the corresponding Schiff bases and phenylhydrazones. Tetrahedron Lett 2001;42:8435-39.

20. Jursic BS, Stevens ED. Mono C-alkylation and mono C-benzylation of barbituric acids through zinc/acid reduction of acyl, benzylidene, and alkylidene barbiturate intermediates. Tetrahedron Lett 2003;44:2203-10.

21. Handbuch Der Örganischen Chemie, Beilstein 24:242.

22. Blotny G. Reactivity of dithiocarbamic esters: methods for the preparation of 3,5 substituted 2-thiohydantoins. Synthesis 1983;391-92.

23. Allan JAV, Deacon BD. Org Synth Coll Vol 4. P 569.

24. Zhivotova TS, Gazaliev AM, Fazylov SD, Aitpaeva ZK, Turdybekov DM. Synthesis and structure of some imidazolidine-2-thiones. Russ J Org Chem 2006;42:448-50.

25. Weatherburn MW. Phenol-hypochlorite reaction for determination of ammonia. Anal Chem 1967;39:971-74.

26. Lowry OH, Rosebrough NJ, Farr AL, Randall RJ. Protein measurement with the folin phenol reagent. J Biol Chem 1951;193:265-75. 